\title{
EFEKTIVITAS PENAMBAHAN CAIRAN ADITIF DALAM PENINGKATAN DAYA DUKUNG TANAH ORGANIK
}

\author{
Ignatius Ega Renaldi ${ }^{1}$ dan Aniek Prihatiningsih ${ }^{2}$ \\ ${ }^{1}$ Program Studi Sarjana Teknik Sipil, Universitas Tarumanagara, Jl. Letjen S. Parman No.1 Jakarta \\ ignatius.325160132@stu.untar.ac.id \\ ${ }^{2}$ Program Studi Sarjana Teknik Sipil, Universitas Tarumanagara, Jl. Letjen S. Parman No.1 Jakarta \\ aniekp@ft.untar.ac.id
}

\begin{abstract}
Organic soil is soil with a mixture of organic materials and the remain of plants and animals. Organic soil is classified as soft soil and divided into several parts, namely organic clay, organic silt, and peat. Carrying capacity of soil is the strength of soil to hold a load acting on soil that is normally distributed through the foundation. In calculating the carrying capacity of the soil, parameters greatly affect are cohesion and angle of shear. Cohesion is the force between particles in rocks with the same molecule. Meanwhile, the angle of shear is the angle formed from normal stress and shear stress in the soil or rock material. Calculation of cohesion and angle of shear of soil can be done with direct shear and triaxial test based on American Standard in Test and Materials (ASTM). In this study, an analysis conducted to determine the best waste liquid additive material. Beside being able to increase the carrying capacity of organic soils, this study can reduce existing waste. The result of this test is all additive can be increasing the value of soil compressive strength. Oil is the best additive which effective to increasing about $300 \%$ value of compressive strength.
\end{abstract}

Keywords: organic soil; cohesion; angle of shear; triaxial test; additive material

\begin{abstract}
ABSTRAK
Tanah Organik adalah tanah yang memiliki campuran bahan-bahan organik dan sisa-sisa pelapukan tumbuhan dan hewan. Tanah organik merupakan tanah yang tergolong tanah lunak dan terbagi menjadi beberapa bagian yaitu tanah lempung organik, lanau organik, dan gambut. Daya dukung tanah adalah kekuatan tanah untuk menahan suatu beban yang bekerja pada tanah yang biasa disalurkan melalui fondasi. Dalam perhitungan daya dukung tanah, parameter yang sangat mempengaruhi adalah kohesi dan sudut geser dalam tanah. Kohesi adalah gaya tarik menarik antar partikel dalam batuan yang molekulnya sama. Sementara itu, sudut geser dalam tanah merupakan sudut yang terbentuk dari hubungan antara tegangan normal dan tegangan geser dalam material tanah atau batuan. Cara mendapatkan nilai kohesi dan sudut geser dalam tanah dapat dilakukan dengan tes direct shear dan triaxial berdasarkan standar amerika. Bahan aditif yang digunakan dalam penelitian ini digunakan bahan cairan yang merupakan bahan sisa atau sampah yang ada dalam masyarakat. Sehingga, selain meningkatkan daya dukung tanah organik penelitian ini dapat mengurangi sampah yang ada. Kesimpulan pada penelitian adalah penambahan cairan aditif dinilai mampu meningkatkan kekuatan geser tanah. Oli bekas dinilai sebagai bahan aditif terbaik yang mampu meningkatkan sebesar $300 \%$ nilai kekuatan geser tanah.
\end{abstract}

Kata kunci: tanah organik; kohesi; sudut geser dalam; tes triaksial; bahan aditif

\section{PENDAHULUAN}

Dunia konstruksi di Indonesia mengalami penambahan seiring dengan pembangunan yang dilakukan secara terusmenerus oleh pemerintah. Salah satu hal yang menandai perkembangan dunia konstruksi adalah semakin banyaknya pembangunan gedung-gedung bertingkat yang tak hanya dapat dilihat di Jakarta saja, melainkan juga di berbagai daerah di seluruh Indonesia. Wacana pemindahan ibu kota negara menjadi salah satu topik terhangat dewasa ini. Dalam sebuah pembicaraan mengenai pemindahan ibu kota semua aspek dipikirkan mulai dari pembebasan lahan, akses serta bangunan yang nantinya dibangun di atas tanah di daerah Kalimantan.

Secara garis besar, struktur utama bangunan dapat dibagi menjadi 2 bagian yaitu struktur atas dan struktur bawah. Struktur atas adalah bangunan yang dapat dilihat secara fisik dan dapat dipakai oleh manusia. Struktur bawah biasa disebut dengan fondasi yang berfungsi memikul bangunan struktur atas. Tanah adalah permukaan bumi atau 
lapisan bumi yang terletak di paling atas dan tanah dapat juga diartikan dengan keadaan bumi disuatu tempat (Nasional). Secara garis lurus penopang struktur bawah (fondasi) berhubungan langsung dengan tanah. Maka dari itu sangatlah penting mengetahui apa jenis tanah yang ada di pulau Kalimantan.

Tanah organik adalah jenis tanah permukaan yang memiliki campuran bahan-bahan organik dan sisa-sisa pelapukan tanaman dan hewan (Wiratama, 2013) yang menjadi mayoritas tanah di pulau Kalimantan. Ciri-ciri tanah organik adalah teksturnya lunak, berwarna tua, dan mudah sekali berubah bentuk jika ditekan (mudah dihancurkan ketika kering) selain itu, tanah organik memiliki kuat geser yang kecil dan kompresibilitas tinggi. Bahan-bahan organik yang terdapat pada tanah organik memiliki tingkat kohesi dan plastisitas yang rendah. Mengingat bahwa tanah gambut adalah bagian dari tanah organik, maka dilakukan beberapa tes pada laboratorium mekanika tanah. Dalam hal ini dapat dilakukan dengan bermacam-macam tes yang memberikan nilai kohesi dan sudut geser dalam seperti unconfined, triaxial, dan direct shear.

Pada konstruksi gedung yang berhubungan langsung dengan tanah, perlu diketahui apa saja parameter tanah yang dipakai dalam pelaksanaan konstruksi. Seperti yang sudah diketahui tanah gambut merupakan tanah lunak yang memperlukan fondasi hingga tanah keras. Diperlukan beberapa perbaikan untuk meningkatkan daya dukung tanah. Perbaikan dapat dilakukan secara mekanikal yaitu dengan menambahkan sesuatu bahan aditif di dalam tanah yang berbentuk padatan dan dilakukan pengadukan. Perbaikan selanjutnya dilakukan dengan cara chemical yaitu dengan menambahkan suatu bahan aditif cairan dengan cara penyemprotan langsung tanpa mengaduk tanah yang ada.

Peningkatan daya dukung tanah organik merupakan salah satu pekerjaan awal yang penting dalam melakukan pekerjaan konstruksi bangunan gedung selanjutnya. Fungsi peningkatan daya dukung dilakukan agar fondasi yang dipasang dapat dilakukan pengiritan serta pembangunan dapat dilakukan lebih mudah dalam menghindari penurunan konsolidasi.

Adapun batasan dari masalah-masalah yang akan diletiti pada penelitian ini, antara lain:

1. Tanah yang digunakan adalah tanah organik yang terdapat di DKI Jakarta.

2. Bahan aditif yang digunakan adalah cairan dan bahan sisa yang berasal dari sampah masyarakat sekitar yaitu oli bekas, minyak goreng yang sudah menghitam, abu terbang serta minyak tanah dan pupuk urea.

3. Objek studi kasus untuk penelitian ini adalah penaikan daya dukung (nilai kohesi dan sudut geser dalam) pada tanah organik.

4. Perhitungan daya dukung tanah organik dilakukan dengan triaxial test yang disertai dengan tes index properties.

Berdasarkan latar belakang, tujuan dari penelitian ini adalah sebagai berikut:

1. Mendapatkan bahan aditif cairan yang terbaik dalam menaikan daya dukung tanah organik.

2. Mendapatkan efisiensi penambahan bahan aditif pada tanah organik.

\section{Dasar teori}

Menurut ASTM D2487-10 (2007), tanah organik sangat tergatung pada kadar organik (organic content), kadar abu (ash content), kadar serat (fibrous content). Makin tinggi kandungan organiknya makin rendah daya dukungnya (bearing capacity) dan kekuatan gesernya (shear strength), serta makin besar pemampatannya (compressibility). Bahan organik yang terdapat dalam tanah dapat dikategorikan sebagai unsur dan senyawa kimia yaitu karbon, nitrogen, dan fostat.

\section{Oli bekas}

Limbah sisa oli sangat sering ditemukan, misalnya di bengkel motor atau mobil disepanjang jalan di Jakarta. Pengunaan kendaraan bermotor yang sangat banyak membuat kehadiran oli yang sebagai pelumas sangat merajalela. Jumlah limbah yang tidak terkontrol akan menjadi pencemaran lingkungan. Penggunaan pada penelitian ini diharapkan dapat membantu mengurangi bahan yang dibuang oleh masyarakat.

\section{Minyak jelantah bekas}

Penggunaan minyak jelantah yang dipakai pada masyarakat sangat banyak dan luas sehingga bahan sisa dari minyak dapat menjadi sebuah kendala dalam penanganan limbah. Maka dari itu, perlu dilakukan penelitian untuk memanfaatkan bahan bekas yang ada. Minyak yang dipakai dalam penelitian ini adalah minyak jelantah yang sudah menghitam.

\section{Pupuk urea}


Pupuk urea merupakan bahan yang digunakan untuk menyuburkan tanaman yang merupakan senyawa organik yang tersusun dari unsur hidrogen, karbon, oksigen dan nitrogen dengan rumus kimia $\mathrm{CON}_{2} \mathrm{H}_{4}$ ataupun $\left(\mathrm{NH}_{2}\right)_{2} \mathrm{CO}$. Di dalam tanah, urea akan terhidrolisis dan melepaskan ion ammonium. Pada umumnya reaksi tanah baik tanah gambut maupun tanah mineral menunjukkan sifat kemasaman atau alkalinitas tanah yang dinyatakan dengan nilai pH. Nilai pH menunjukkan banyaknya konsentrasi ion Hidrogen $\left(\mathrm{H}^{+}\right)$di dalam tanah. Makin tinggi kadar ion $\mathrm{H}^{+}$di dalam tanah, semakin masam tanah tersebut. Di dalam tanah selain $\mathrm{H}^{+}$dan ion-ion lain ditemukan pula ion $\mathrm{OH}^{-}$, yang jumlahnya sebanding dengan banyaknya $\mathrm{H}^{+}$.

\section{Minyak tanah}

Minyak tanah yang juga dikenal sebagai parafin, minyak lampu, dan minyak batu bara adalah cairan hidrokarbon yang mudah terbakar yang berasal dari minyak bumi. Minyak tanah merupakan bahan yang tidak mudah terbakar dan merupakan turunan dari minyak bumi.

\section{Abu terbang}

Menurut ASTM C618 dalam Susilo (2016) mengidentifikasi dua kelas fly ash. Abu terbang kelas C berasal dari pembakaran batubara muda lignit atau sub bituminous. Biasanya mengandung lebih dari 20\% kapur api (CaO). Dan abu terbang kelas F berasal dari pembakaran yang lebih tua atau batubara bitumen. Partikel fly ash hampir bulat karena dibentuk oleh pemadatan mineral cair saat mereka naik cerobong asap di pembangkit listrik. Fly ash dikumpulkan di cerobong asap menggunakan air dan lumpur yang dihasilkan secara hidrolis di timbunan tempat pembuangan akhir untuk pengisian lahan berikutnya.

\section{Tes triaksial}

Pada penelitian ini dipakai tes triaksial dengan unconsolidated-undrained yang diatur dengan ASTM D2850-03a (Standard Test Method for Unconsolidated-Undrained Triaxial Compression Test on Cohesive Soils). Tes ini digunakan untuk menentukan hubungan kekuatan dan tegangan-regangan dalam sampel silinder (undrained strength properties dan stress-strain relations). Tidak memerlukan drainase dalam tes ini.

\section{METODE PENELITIAN}

Proses analisis data dimulai dengan tahap informasi, di mana dalam tahapan ini akan dilakukan pengumpulan informasi yang diperlukan dalam penelitian ini, seperti bahan cairan bekas yang akan digunakan, tanah organik yang akan diuji, serta melihat beberapa kajian dari penelitian sebelumnya dalam bentuk jurnal maupun buku. Setelah itu adalah tahap fungsi, pada tahap ini akan dilakukan pendefinisian fungsi peningkatan daya dukung tanah serta mencari standar tes yang digunakan untuk penelitian. Tahap selanjutnya adalah tahap pengumpulan data, pada tahap ini akan dilakukan serangkaian penelitian pada laboratorium mekanika tanah Universitas Tarumanagara. Kemudian akan dilanjutkan dengan tahap analisis data, di mana akan dilakukan analisis terhadap data yang sudah diperoleh. Tahapan terakhir dalam proses pengolahan data ini adalah tahap rekomendasi, di mana akan dipaparkan hasil dari analisis yang telah dilakukan, serta memberikan rekomendasi berdasarkan hasil yang telah diperoleh.

Penelitian yang digunakan adalah pengujian sampel tanah organik pada laboratorium mekanika tanah. Penelitian ini dilakukan dengan cara mengambil tanah organik yang terletak di Jakarta. Kemudian tanah yang diambil akan dipisah masuk kontainer dan zipper lock. Fungsi dari pemisahan dari tanah adalah untuk memisahkan sampel tanah agar tercapai kondisi yang tidak terganggu pada sampel yang belom ingin diuji. Pada saat tanah sampai di laboratorium, tanah harus langsung dites index properties untuk mengetahui batas-batas Atterberg, grainsize analysis serta water content. Setelah mengetahui parameter dasar tanah, maka dilakukan tes triaksial untuk tanah organik dengan metode Unconsolidated-Undrained tanpa ditambah adiktif untuk menjadi kontrol pada penelitian ini. Sesudah itu dilakukan penelitian dengan menambahkan atau mengkombinasikan antara bahan aditif cairan yang telah dipersiapkan sebelumnya. Kemudian diambil data yang ada sesuai dengan penelitian di laboratorium mekanika tanah.

Tanah yang digunakan pada penelitian ini berlokasi di Jakarta. Tanah yang digunakan adalah tanah organik. Selain tanah organik, bahan adiktif yang digunakan adalah oli bekas dari salah satu bengkel di Jakarta Barat, minyak goreng bekas dari salah satu penjual gorengan di Jakarta Barat, minyak tanah bening dari toko kelontong di Cengkareng, pupuk urea dari tukang tanaman di Jakarta Barat, dan abu terbang yang berasal dari batching plan di Jakarta Barat. Setelah mengambil data pada laboratorium mekanika tanah, data diolah dengan cara perhitungan dengan beberapa rumus dari batas batas Atteberg, specific gravity, grainsize analysis, dan water content. Serta data dari tes triaksial akan dibandingkan dari yang menggunakan bahan aditif dan yang tidak menggunakan campuran aditif. 


\section{HASIL DAN PEMBAHASAN}

Tanah yang sudah diambil dari lapangan dikeringkan terlebih dahulu selama beberapa hari. Setelah kering, tanah dimasukan kedalam gelas uji yang dibagi menjadi beberapa sampel. Setiap gelas uji mempunyai label nama yang berbeda-beda yang menandakan campuran yang dimasukkan kedalam gelas uji. Sampel yang diuji disemprotkan bahan kimia aditif dan didiamkan selama 24 jam untuk membiarkan cairan meresap sampai kedalam. Tanah yang digunakan dalam tes, dibagi dalam 6 sampel dan masing masing sampel memiliki 10 atau 5 gelas uji. Sebelum tanah dituang kedalam gelas uji, dilakukan penyaringan terlebih dahulu supaya butiran tanah menjadi seragam dan hasil tes tidak berbeda jauh simpangan hasilnya. Alat yang dipakai dalam pengujian ini adalah pocket penetrometer. Fungsinya adalah mengetahui perkiraan nilai UCT (unconfined compression test)pada tanah. Untuk membacanya pertama lepaskan tutup merah pada alat, lalu geser ring putih pada alat hingga angka 0. Setelah itu dilakukan penusukan alat kedalam tanah sebatas leher alat dan hasilnya langsung dapat dibaca pada alat pocket penetrometer. Satuan yang dipakai dalam pembacaan alat adalah $\mathrm{kg} / \mathrm{cm}^{2}$. Sampel dibagi menjadi 6 sampel dengan hasil sebagai berikut:

Tabel 1. Hasil pengujian sampel I

\begin{tabular}{|c|c|c|c|}
\hline SAMPEL I & & Lokasi: & Jakarta Utara \\
\hline No Sampel & Nilai pembacaan $\left(\mathrm{kg} / \mathrm{cm}^{2}\right)$ & Keterangan & Tanggal percobaan \\
\hline 1 & 0,25 & Tanpa campuran & 1-Apr-20 \\
\hline 2 & 0,3 & Tanpa campuran & 1-Apr-20 \\
\hline 3 & 0,5 & Urea & 1-Apr-20 \\
\hline 4 & 0,4 & Urea & 1-Apr-20 \\
\hline 5 & 0,5 & Minyak Tanah & 1-Apr-20 \\
\hline 6 & 0,4 & Minyak Tanah & 1-Apr-20 \\
\hline 7 & 0,75 & Minyak Jelantah & 1-Apr-20 \\
\hline 8 & 0,6 & Minyak Jelantah & 1-Apr-20 \\
\hline 9 & 0,75 & Oli & 1-Apr-20 \\
\hline 10 & 1 & Oli & 1-Apr-20 \\
\hline
\end{tabular}

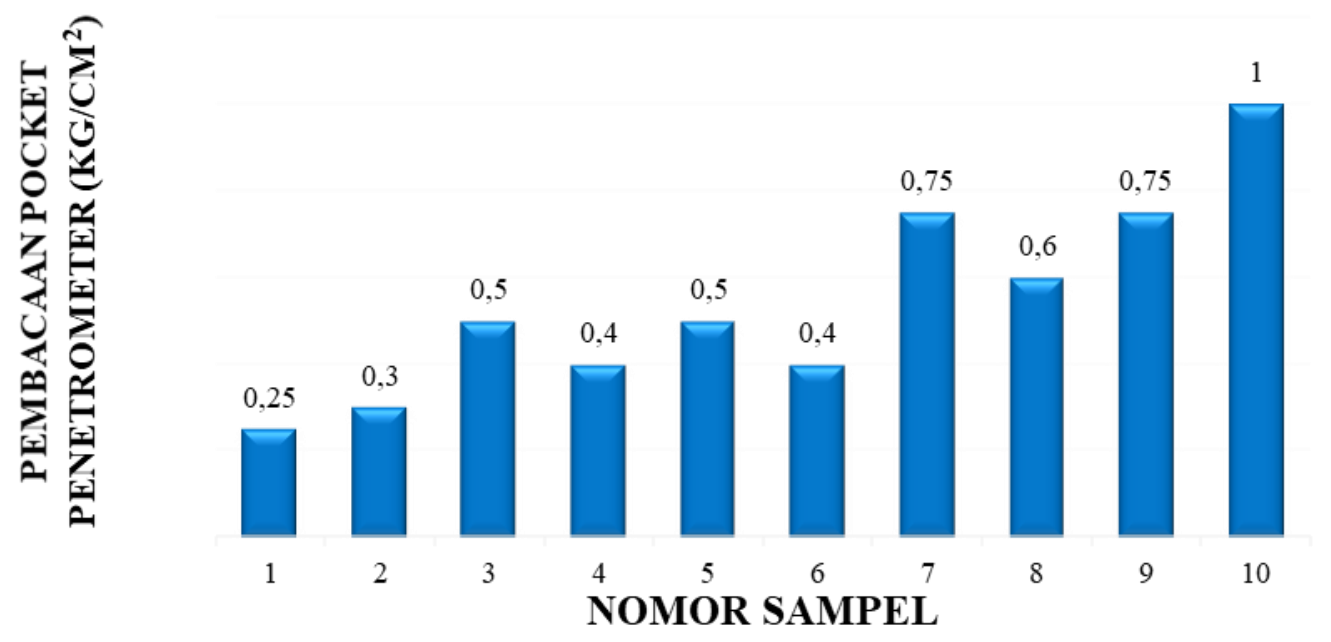

Gambar 1. Hasil penelitian sampel I 
Hasil percobaan pembacaan pocket penetrometer sampel I dapat dilihat pada tabel 1 dan gambar 1 yang menyatakan bahwa penggunaan oli menjadi bahan yang efektif dalam meningkatkan daya dukung tanah organik sampel I.

Tabel 2. Hasil pengujian sampel II

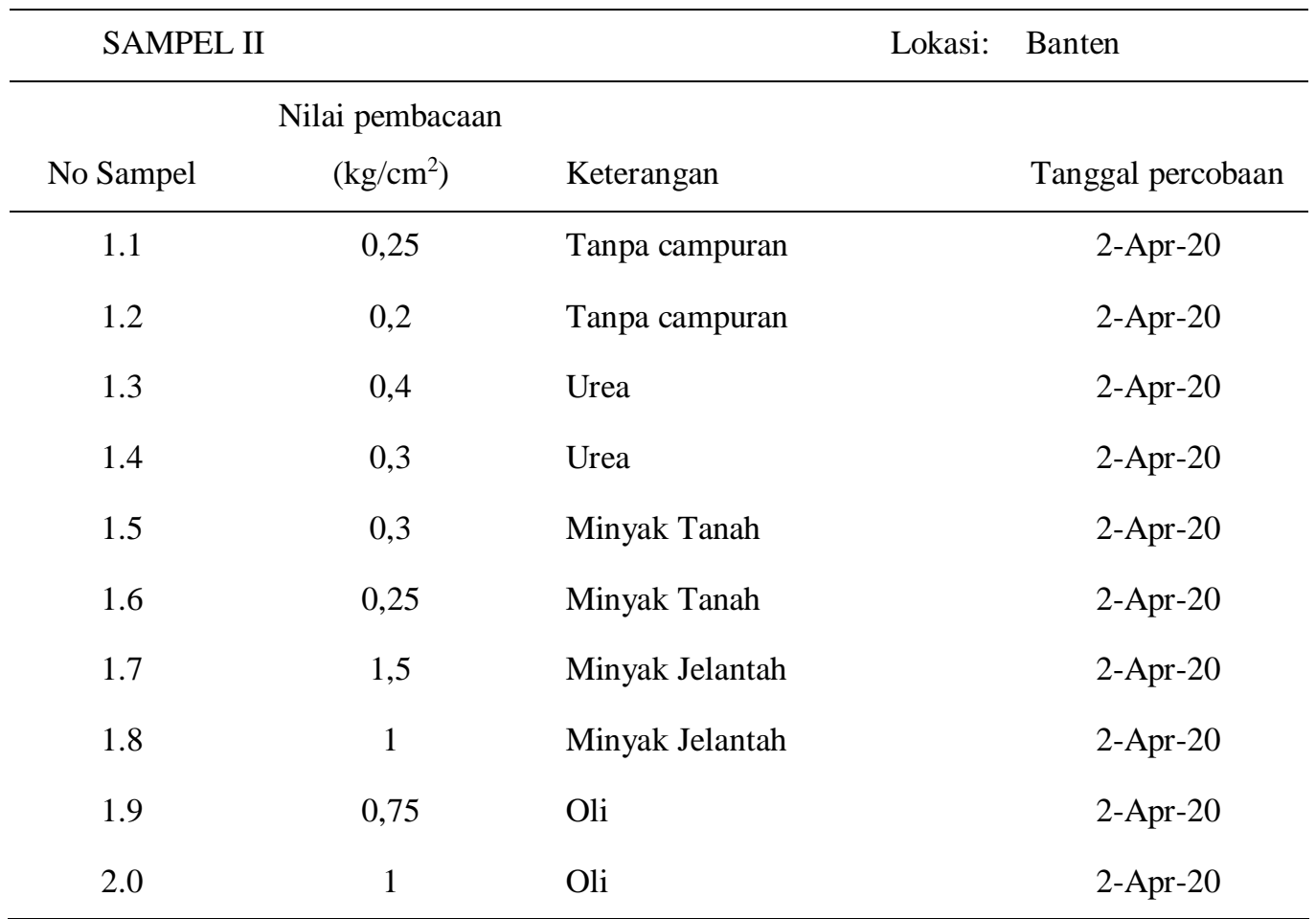
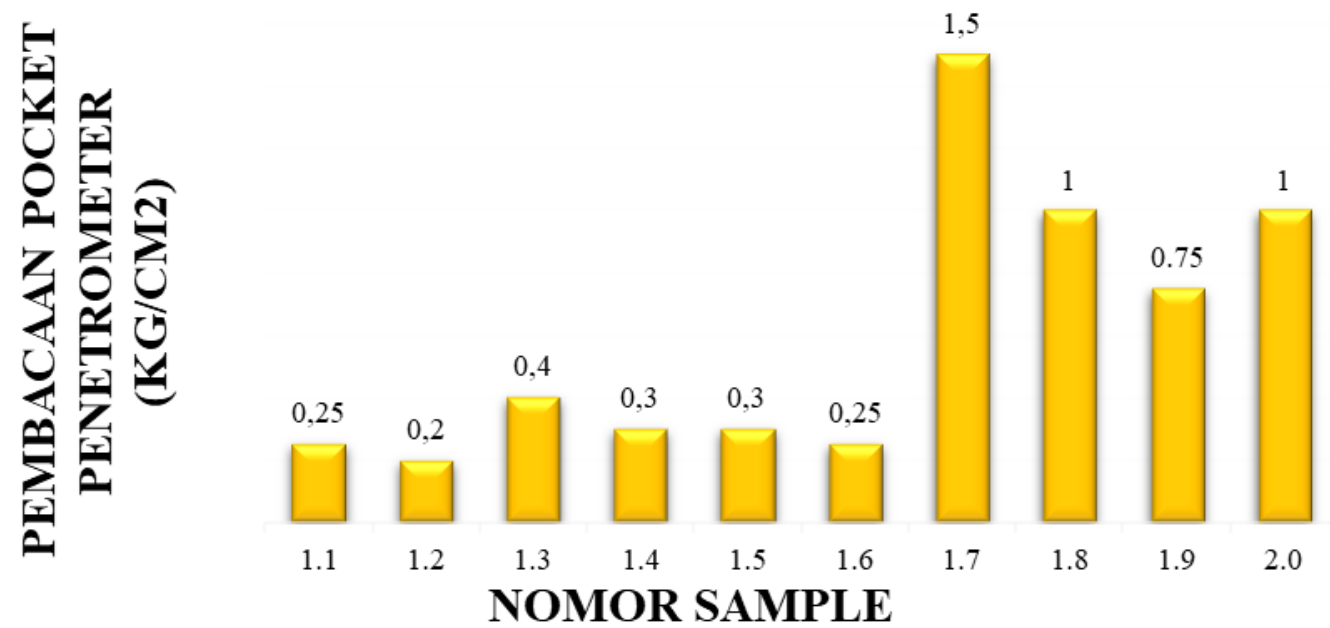

Gambar 2. Hasil penelitian sampel II

Hasil percobaan pembacaan pocket penetrometer sampel II dapat dilihat pada tabel 2 dan gambar 2 yang menyatakan bahwa penggunaan minyak jelantah menjadi bahan yang efektif dalam meningkatkan daya dukung tanah organik sampel II. 
Tabel 3. Hasil pengujian sampel III

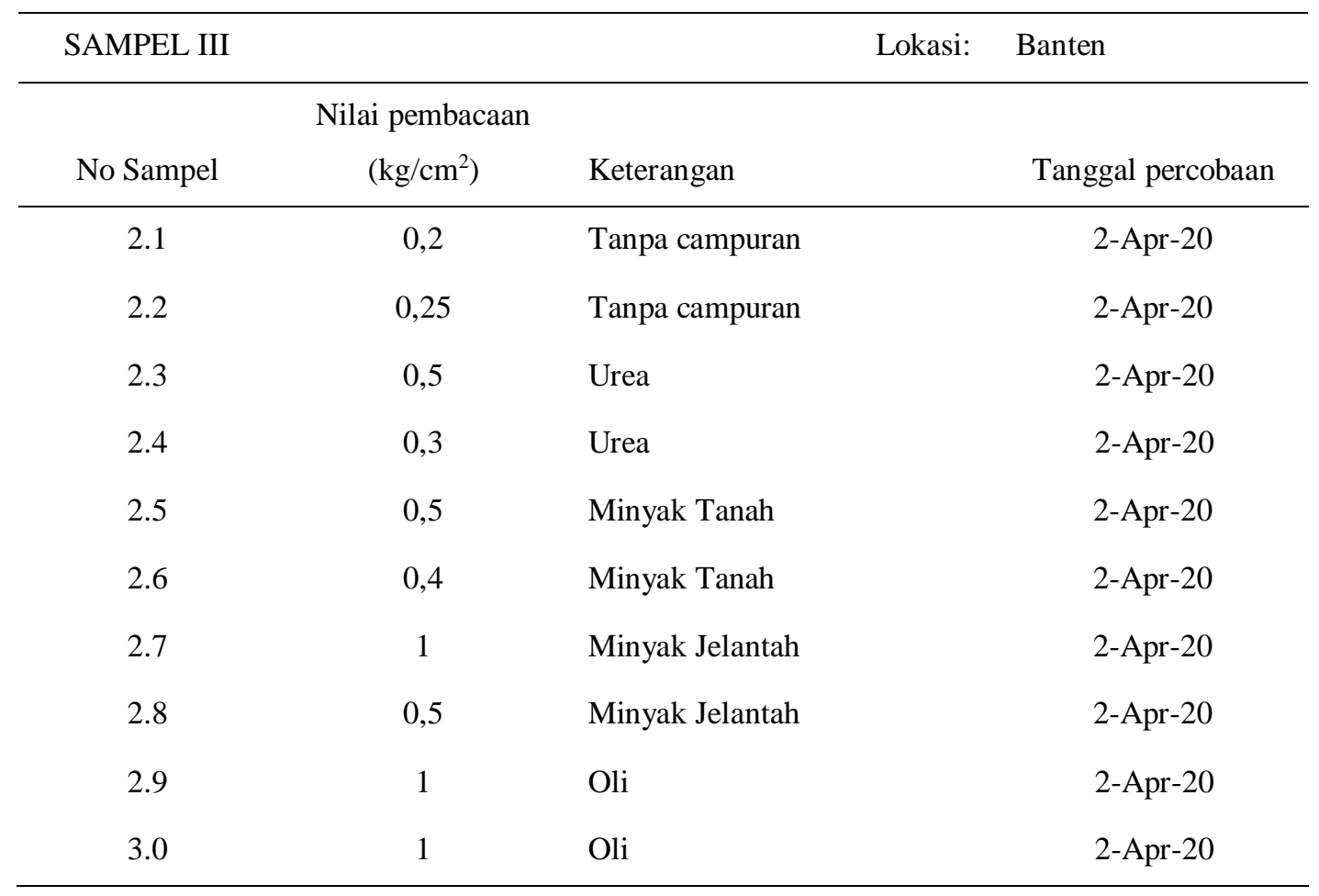

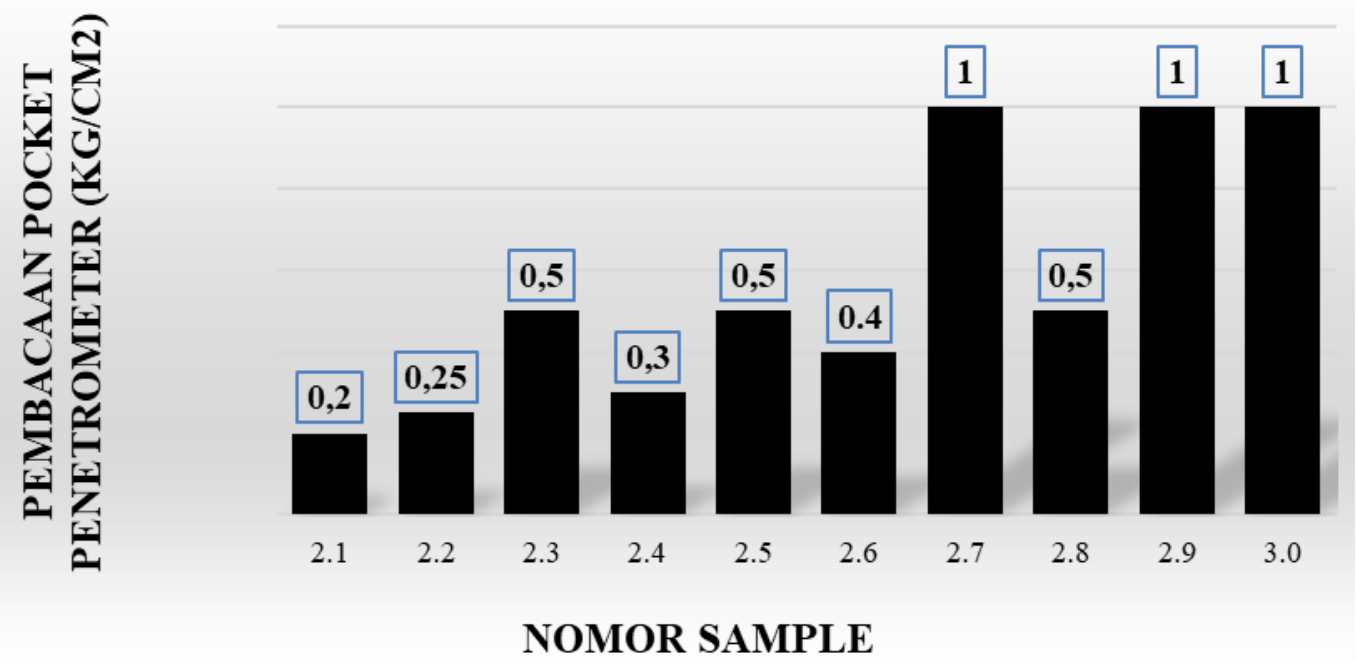

Gambar 3. Hasil pengujian sampel III

Hasil percobaan pembacaan pocket penetrometer sampel III dapat dilihat pada tabel 3 dan gambar 3 yang menyatakan bahwa penggunaan minyak jelantah dan oli menjadi bahan yang efektif dalam meningkatkan daya dukung tanah organik sampel III. 
Tabel 4. Hasil pengujian sampel IV

\begin{tabular}{cclc}
\hline SAMPEL IV & & & Lokasi: Jakarta Utara \\
\hline No Sampel & Nilai pembacaan & & \\
3.1 & $\left(\mathrm{~kg} / \mathrm{cm}^{2}\right)$ & Keterangan & Tanggal percobaan \\
3.2 & 0,3 & Tanpa campuran & $4-A p r-20$ \\
3.3 & 0,75 & Urea & $4-A p r-20$ \\
3.4 & 0,3 & Minyak Tanah & $4-A p r-20$ \\
3.5 & 0,8 & Minyak Jelantah & $4-A p r-20$ \\
\hline
\end{tabular}

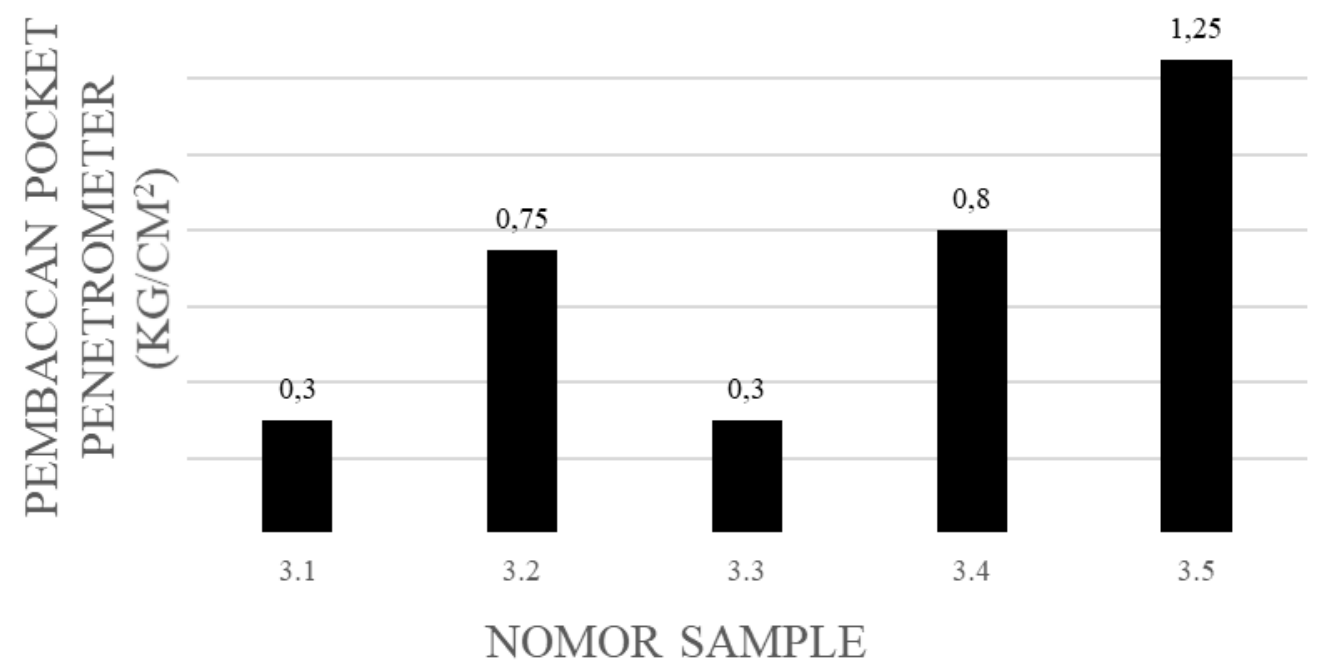

Gambar 4. Hasil pengujian sampel IV

Hasil percobaan pembacaan pocket penetrometer sampel IV dapat dilihat pada tabel 4 dan gambar 4 yang menyatakan bahwa penggunaan oli menjadi bahan yang efektif dalam meningkatkan daya dukung tanah organik sampel IV.

Tabel 5. Hasil pengujian sampel V

\begin{tabular}{cclc}
\hline SAMPEL V & & & Lokasi: Banten \\
\hline No Sampel & Nilai pembacaan $(\mathrm{kg} / \mathrm{cm} 2)$ & Keterangan & Tanggal percobaan \\
\hline 4.1 & 0,25 & Tanpa campuran & 5-Apr-20 \\
4.2 & 0,5 & Urea & 5 -Apr-20 \\
4.3 & 0,4 & Minyak Tanah & 5-Apr-20 \\
4.4 & 1 & Minyak Jelantah & 5-Apr-20 \\
4.5 & 1,25 & Oli & $5-A p r-20$ \\
\hline
\end{tabular}




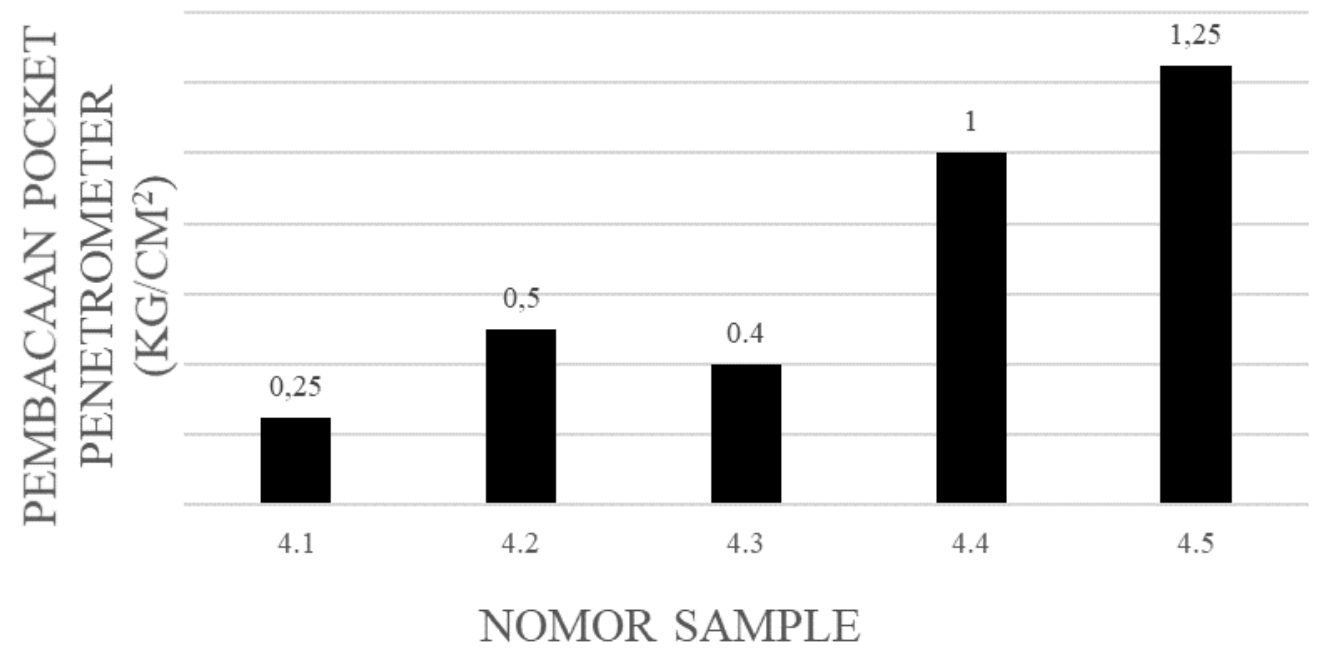

Gambar 5. Hasil pengujian sampel V

Hasil percobaan pembacaan pocket penetrometer sampel V dapat dilihat pada tabel 5 dan gambar 5 yang menyatakan bahwa penggunaan oli menjadi bahan yang efektif dalam meningkatkan daya dukung tanah organik sampel V.

Tabel 6. Hasil pengujian sampel VI

\begin{tabular}{cclc}
\hline SAMPEL VI & & & Lokasi: Banten \\
\hline No Sampel & Nilai pembacaan $(\mathrm{kg} / \mathrm{cm} 2)$ & Keterangan & Tanggal percobaan \\
\hline 5.1 & 0,25 & Tanpa campuran & 6 -Apr-20 \\
5.2 & 0,25 & Urea & $6-A p r-20$ \\
5.3 & 0,4 & Minyak Tanah & $6-A p r-20$ \\
5.4 & 0,5 & Minyak Jelantah & 6-Apr-20 \\
5.5 & 1 & Oli & 6-Apr-20 \\
\hline
\end{tabular}




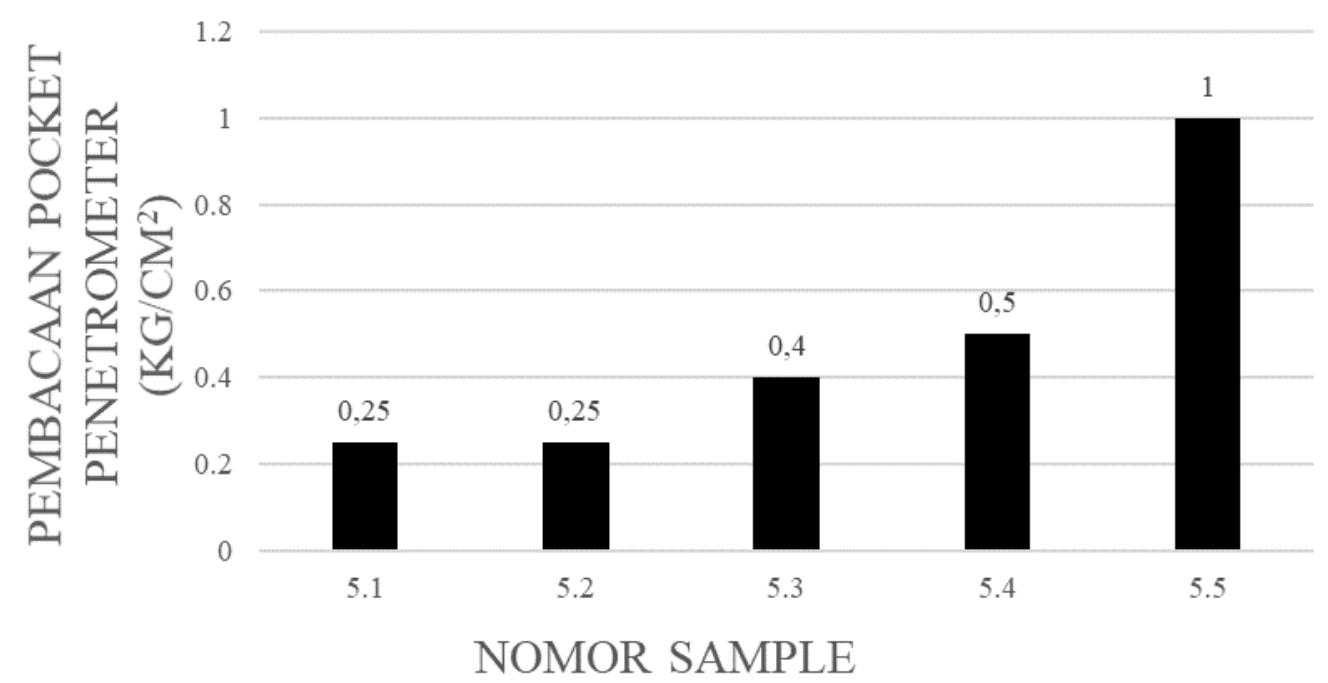

Gambar 6. Hasil pengujian sampel VI

Hasil percobaan pembacaan pocket penetrometer sampel VI dapat dilihat pada tabel 6 dan gambar 6 yang menyatakan bahwa penggunaan oli menjadi bahan yang efektif dalam meningkatkan daya dukung tanah organik sampel VI. Selain tabel dan grafik hasil pengujian sampel pocket penetrometer ditampilkan juga grafik hasil superimposed dari pengujian diatas.

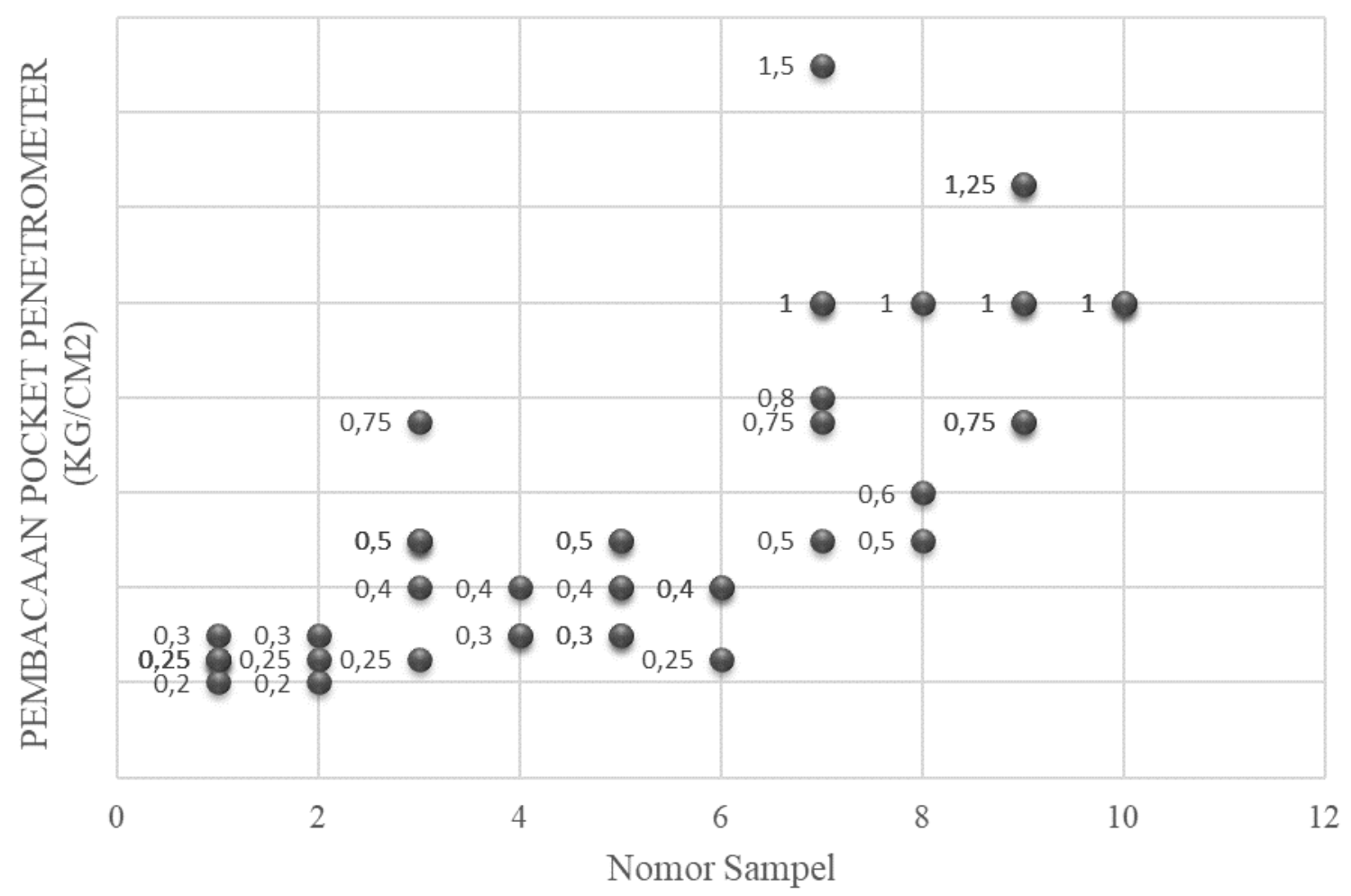

Gambar 7. Superimposed pengujian semua sampel

Berdasarkan gambar dan tabel yang telah disajikan diatas, seluruh campuran dinyatakan mampu meningkatkan kekuatan tanah. Didapatkan berbagai hasil yang berbeda-beda pada setiap campuran bahan aditif yang dipengaruhi oleh perbedaan lokasi dan kedalaman sampel tanah organik. Kemampuan minyak jelantah dan oli dinilai menjadi yang paling efektif dalam meningkatan nilai UCT (unconfined compression test) pada tanah. Sedangkan urea dan minyak tanah mampu sedikit meningkatkan nilai UCT dalam pembacaan alat pocket penetrometer. Grafik 
superimposed menjelaskan bahwa setiap sampel aditif memiliki efektifitas yang berbeda-beda dalam perkuatan tanah dibandingkan dengan tanah yang tidak mengalami campuran aditif (sampel nomor 1 dan 2). Analisis dilanjutkan pada perhitungan presentase kenaikan setelah pencampuran bahan aditif yang dapat dilihat dalam tabel berikut.

Tabel 7. Presentase kenaikan daya dukung tanah

\begin{tabular}{lccccc}
\hline Keterangan & Tanpa Campuran & Urea & Minyak Tanah & Minyak Jelantah & Oli \\
\hline $\begin{array}{l}\text { Rata-rata hasil pembacaan pocket } \\
\text { penetrometer }\left(\mathrm{kg} / \mathrm{cm}^{2}\right)\end{array}$ & 0,25 & 0,43 & 0,38 & 0,85 & 1.00 \\
$\begin{array}{l}\text { Perbandingan kenaikan daya } \\
\text { dukung tanah }(\%)\end{array}$ & 0,00 & 73,33 & 53,33 & 240,00 & 300,00 \\
\hline
\end{tabular}

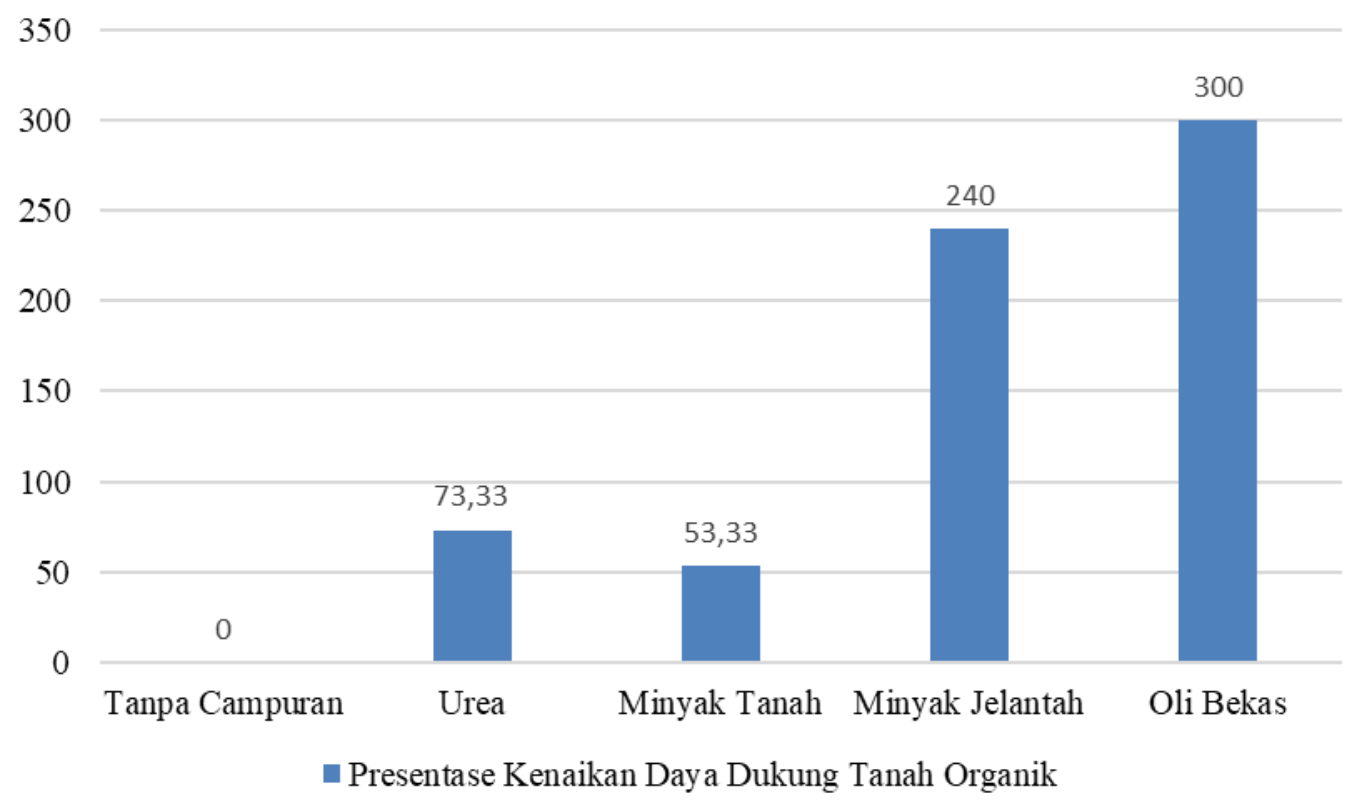

Gambar 8. Presentase kenaikan daya dukung tanah organik

Perbandingan nilai pembacaan pocket penetrometer rata-rata yang didapat dari pengujian diperoleh hasil bahwa pencampuran tanah organik dengan bahan aditif urea mengalami kenaikan nilai kuat tekan terhadap kekuatan dari tanah organik itu sendiri sebesar $73,33 \%$, pencampuran dengan aditif minyak tanah mengalami kenaikan sebesar $53,33 \%$, ditambah aditif minyak jelantah juga mengalami peningkatan sebesar $240 \%$, sedangkan pencampuran tanah organik dengan bahan aditif oli bekas mengalami kenaikan pula sebesar $300 \%$ dan menjadi bahan aditif terbaik dalam meningkatkan daya dukung tanah organik. Dapat disimpulkan bahwa penambahan bahan aditif dapat meningkatan kekuatan terhadap tanah organik itu sendiri.

\section{KESIMPULAN DAN SARAN}

\section{Kesimpulan}

Berdasarkan seluruh hasil penelitian yang telah dilakukan pada efektivitas penambahan cairan aditif dalam peningkatan daya dukung tanah organik maka dapat disimpukan bahwa:

1.Penambahan cairan aditif secara keseluruhan mampu meningkatkan nilai UCT (unconfined compression test) pada tanah jika dibandingkan langsung dengan tanah yang tidak diberi campuran.

2.Penambahan cairan aditif dilakukan dengan jumlah takaran yang berbeda-beda untuk memastikan seluruh cairan aditif dapat diserap dengan baik oleh tanah. Hal yang mempengaruhi banyaknya takaran cairan aditif yang diberikan untuk sampel adalah konsentrasi cairan aditif dan permeabilitas tanah yang akan diuji.

3. Tanah organik yang ditinjau berasal dari Jakarta dan hanya diamati dari sifat fisik tanah yang meliputi warna dan kandungan tanah yang dapat diamati oleh mata. 
4.Pada tanah pasir organik yang memiliki kandungan kerang, campuran oli menjadi bahan aditif yang paling efektif dalam meningkatkan nilai UCT (unconfined compression test).

5.Pada salah satu tanah lempung kecoklatan, campuran minyak goreng menjadi bahan aditif yang efektif dalam meningkatkan nilai UCT (unconfined compression test).

6.Oli menjadi bahan aditif yang paling dominan dalam meningkatkan daya dukung tanah selanjutnya disusul oleh minyak goreng, minyak tanah, dan urea.

\section{Saran}

Untuk melengkapi dan meningkatkan penelitian efektivitas penambahan cairan aditif dalam peningkatan daya dukung tanah organik diperlukan untuk:

1.Diperlukan penelitian lebih lanjut untuk mengetahui indeks properties tanah yang diuji.

2.Diperlukan waktu yang lebih lama untuk melakukan penyerapan bahan aditif kedalam tanah apabila tanah yang diuji berada dalam kedalaman yang sangat dalam.

3.Tanah yang diteliti hanya dilihat dari sifat fisiknya saja, dibutuhkan penelitian selanjutnnya untuk mengetahui kenaikan yang signifikan dalam penggunaan bahan aditif.

\section{DAFTAR PUSTAKA}

ASTM International. ASTM D2487-10 Standard Practice for Classification of Soils for Engineering Purposes (Unified Soil Classification System). United States: American Society for Testing and Material, 2012.

ASTM International. ASTM D2850-03a, Standard Test Method for Unconsolidated-Undrained Triaxial

Compression Test on Cohesive Soil. United States: American Society for Testing and Material, 2012.

Departemen Pendidikan Nasional, Kamus Besar Bahasa Indonesia. Vol.3. Jakarta: Balai Pustaka, 2008.

Susilo, Alfred Jonathan, Enhancing the Strength Properties of Fly Ash by Adding Waste Products. UKnowledge: Theses and Dissertations, 2016.

Wiratama, M. Sendi, Studi Daya Dukung Tanah Organik Menggunakan Matos. Digital Repository Unila, 2013. 
Efektivitas Penambahan Cairan Aditif dalam Peningkatan

Ignatius Ega Renaldi, et al. Daya Dukung Tanah Organik 